\title{
STRATEGI PENGHIDUPAN PETERNAK SAPI PERAH DI LERENG SELATAN GUNUNGAPI MERAPI PASCA ERUPSI 2010
}

\section{STRATEGIES FOR DAIRY FARMERS LIVELIHOOD IN THE SOUTHERN SLOPE OF MERAPI VOLCANO AFTER ERUPTION 2010}

\author{
Siti Andarwati ${ }^{1 *}$, Rijanta $^{2}$, Rini Widiati ${ }^{1}$, dan Yanin Opatpatanakit ${ }^{3}$ \\ ${ }^{1}$ Fakultas Peternakan, Universitas Gadjah Mada, Yogyakarta, 55281 \\ ${ }^{2}$ Fakultas Geografi, Universitas Gadjah Mada, Yogyakarta, 55281 \\ ${ }^{3}$ Faculty of Animal Science and Technology, Maejo University, Thailand, 50290
}

Submitted: 25 August 2016, Accepted: 9 December 2016

\section{INTISARI}

Penelitian ini bertujuan untuk menganalisis strategi peternak sapi perah di Kawasan Rawan Bencana (KRB) di lereng selatan Merapi dalam mempertahankan penghidupan pasca erupsi gunungapi Merapi 2010. Penelitian dilakukan dengan metode survei. Metode pengambilan sampel dilakukan dengan menggunakan metode Sensus, yaitu dengan mengambil semua peternak yang memenuhi kualifikasi, terdiri dari 84 peternak sapi perah di KRB III (Dusun Kaliadem) dan 50 peternak di KRB II (Dusun Gondang Wetan). Kedua dusun tersebut termasuk wilayah Kecamatan Cangkringan. Guna mengetahui strategi peternak, digunakan metode deskriptif ialah menggali sebanyak mungkin informasi yang berkaitan dengan penghidupan mereka, meliputi tiga aspek penting yaitu aset (livelihood resources), akses dan aktivitas. Analisis statistik yang digunakan untuk klasifikasi strategi penghidupan menggunakan Analisis Faktor dengan bantuan program SPSS versi 18. Hasil penelitian menunjukkan bahwa terdapat sembilan strategi yang dipilih oleh peternak sapi perah dalam mempertahankan sumber penghidupan guna menjamin penghidupan yang berkelanjutan, yaitu: kombinasi pemanfaatan aset finansial, fisik dan sumber daya alam dengan mempertahankan usaha sapi perah; kombinasi pemanfaatan aset fisik dan sosial, akses sosial serta diversifikasi usaha; pemanfaatan akses sosial; pemanfaatan bantuan dan akses sosial secara timbal balik; pemanfaatan liquid aset dan modal sosial; kombinasi faktor psikologis dengan pemanfaatan akses sosial dan finansial; pemanfaatan aset dan akses finansial serta penggunaan waktu jeda; pemanfaatan modal sosial; dan diversifikasi usaha peternakan. Kombinasi pemanfaatan aset finansial, fisik dan sumber daya alam dengan mempertahankan usaha sapi perah merupakan salah satu strategi paling dominan yang dipilih oleh peternak, dengan nilai kumulatif terbesar $(27,64 \%)$. Variabel psikologis yaitu perasaan aman tinggal di lereng Merapi, merupakan temuan variabel baru dalam teori yang mempelajari strategi penghidupan berkelanjutan. Modal sosial merupakan variabel yang mendominasi dasar pilihan strategi penghidupan berkelanjutan peternak sapi perah pasca erupsi Merapi 2010.

(Kata kunci: Akses, Aktivitas, Aset, Gunungapi Merapi, Strategi penghidupan)

\section{ABSTRACT}

This study was aimed to analyze dairy farmers' strategies in disaster prone areas (DPA) at the southern slope of Merapi in sustaining their livelihood after Merapi Volcano eruption in 2010. The research was conducted using survey method. Sampling was done using the census methods, in which all farmers who met qualifications were taken, consisting of 84 dairy farmers in DPA III (Kaliadem hamlet) and 50 dairy farmers in DPA II (Gondang Wetan hamlet). Both hamlets belong to Cangkringan district. To identify farmer' strategies, the descriptive method was applied by gathering as many as information related to their livelihood, including three important aspects: assets (livelihood resources), access and activity. Statistical analysis used for classification of livelihood strategies was Factor Analysis with SPSS version 18. The results showed that there were nine strategies chosen by dairy farmers for sustaining livelihoods in order to ensure sustainable livelihoods: the combination of financial, physical assets and natural resources utilization, as well as maintaining dairy farm; the combination of physical and social capital utilization, social access and business diversification; social access utilization; social support and mutual access utilization, liquid assets and social capital utilization. The combination of psychological factors with financial and social access utilization; financial assets and access utilization, and also the

\footnotetext{
* Korespondensi (corresponding author):

Telp. +62 8122757 202, E-mail: andar_siti@ugm.ac.id
} 
use of pause time; social capital utilization; and farm diversification. The combination of financial, physical assets and natural resources utilization, as well as maintaining the dairy farm was the most dominant strategy chosen by farmers, with the greatest cumulative value (27.64\%). Psychological variable ie feeling safe to live on the slopes of Merapi was to be a new finding in sustainable livelihood strategies theory. Social capital was the variable that dominated the basic options of sustainable livelihood strategy of dairy farmers after the Merapi eruption in 2010.

(Keywords: Access, Activity, Assets, Livelihood strategies, Merapi volcano)

\section{Pendahuluan}

Lereng selatan Merapi yang termasuk dalam Propinsi Daerah Istimewa Yogyakarta, meliputi Kecamatan Tempel pada posisi paling barat, Kecamatan Turi dan Kecamatan Pakem dibagian tengah dan Kecamatan Cangkringan pada posisi paling Timur. Kawasan Rawan Bencana (KRB) gunungapi Merapi dibagi dalam tiga tingkatan dari rendah ke tinggi berturut-turut yaitu KRB gunungapi Merapi I, II, III. KRB III meliputi wilayah 0-5 km dari puncak, KRB II berada $5-10 \mathrm{~km}$ dari puncak dan KRB I berada pada 10-20 km dari puncak Merapi (BNPB, 2010).

Peternakan sapi perah di lereng selatan Merapi sudah dibudidayakan secara turun-temurun oleh masyakarat setempat. Rerata kepemilikan ternak pada anggota koperasi menurut Ilham dan Priyanti (2011) antara 3-5 ekor dengan tingkat produksi susu antara 9-15 liter/ekor/hari. Jumlah sapi induk $50 \%$ dari jumlah ternak yang dipelihara peternak. Populasi sapi perah di lereng selatan Merapi selama kurun waktu tahun 2003 sampai dengan tahun 2011 dapat diamati pada Tabel 1. Populasi sapi perah meningkat selama kurun waktu 2003 sampai dengan tahun 2005, akan tetapi sejak tahun 2006 terus mengalami penurunan. Peningkatan populasi kembali terjadi pada tahun 2009. Tahun 2010 terjadi penurunan sangat tajam terhadap populasi sapi perah dikarenakan adanya musibah erupsi Merapi. Setahun pasca erupsi, mulai terjadi peningkatan populasi kembali, setelah adanya recovery ekonomi korban erupsi Merapi oleh pemerintah yaitu dengan program penggantian sapi mati atau yang ditinggal di lokasi bencana karena harus mengungsi.

Widiati et al. (2007) memaparkan hasil evaluasi sistem usaha peternak sapi perah di kelompok peternak Dadi Makmur, Desa Kepuharjo dengan sistem Lembaga Keuangan Mikro (LKM) menunjukkan kas LKM bernilai positif dan tidak ada tunggakan.
Analisis kelayakan finansiil dengan jangka waktu investasi 5 tahun dan discount factor $12 \%$ per tahun pada kelompok sapi perah Dadi Makmur menunjukkan nilai net present value (NPV) sebesar Rp141.694,00/ekor induk/bulan, benefit cost ratio (BCR) sebesar 2,62 dan internal rate of return (IRR) sebesar $19 \%$. Hasil penelitian menunjukkan bahwa usaha sapi perah dikatakan feasible dan layak diusahakan.

Pendekatan penghidupan yang berkelanjutan seringkali diadopsi untuk pengurangan resiko bencana. Perilaku masyarakat Jawa dalam menghadapi ancaman vulkanik dibentuk oleh interaksi yang kompleks antara persepsi risiko terkait dengan bahaya gunungapi, keyakinan budaya dan kendala sosial ekonomi. Guna mengamankan kebutuhan sehari-hari, matapencaharian mereka lebih berharga dibanding persepsi atas risiko bencana. Akses matapencaharian merupakan faktor penting pada evakuasi penduduk di daerah bahaya, pada kasus Merapi, kemiskinan dan ketahanan pangan merupakan alasan utama (Tobin dan Whiteford, 2002).

Laksono (1998) cit. Lavigne et al. (2008) menggambarkan bagaimana penduduk sekitar lereng Merapi yang bertransmigrasi ke Sumatera memilih segera kembali ke daerah asal (Merapi). Hal ini dikarenakan daerah baru Sumatera mereka anggap sebagai sesuatu yang lebih berbahaya dibanding selama mereka tinggal di lereng Merapi dengan segala kekerabatan dan struktur sosial-ekonomi yang sudah berlangsung sebagai mekanisme bertahan mereka menghadapi bahaya Merapi.

Pasca erupsi gunungapi Merapi tahun 2010, rumah dan kandang sebagian peternak sapi perah rata dengan tanah (hancur) akibat timbunan material vulkanik, sehingga mereka tinggal sementara di pengungsian dan mulai akhir tahun 2012 sudah menempati hunian tetap (Huntap) yang dibuat oleh pemerintah dan sebagian lagi kembali ke dusun semula sebelum 
Buletin Peternakan Vol. 41 (1): 91-100, Februari 2017

Bulletin of Animal Science, DOI: 10.21059/buletinpeternak.v41i1.12768

Tabel 1. Populasi sapi perah di lereng selatan Merapi tahun 2003-2011 (ekor) (dairy population on the southern slopes of Merapi in 2003-2011 (tail))

\begin{tabular}{lrrrrrrrrr}
\hline \hline Kecamatan & 2003 & 2004 & 2005 & 2006 & 2007 & 2008 & 2009 & 2010 & 2011 \\
\hline Tempel & 328 & 374 & 441 & 348 & 284 & 269 & 213 & 178 & 148 \\
Turi & 316 & 368 & 430 & 357 & 335 & 338 & 425 & 444 & 269 \\
Pakem & 3.201 & 3.596 & 3.579 & 3.190 & 2.731 & 2.705 & 2.107 & 2.096 & 1.850 \\
Cangkringan & 2.053 & 2.798 & 3.095 & 2.789 & 2.086 & 2.012 & 2.274 & 25 & 1.042 \\
\hline \\
Sumber : Badan Pusat Statistik Kabupaten Sleman, 2012 (disarikan dari Kabupaten Sleman Dalam Angka tahun 2003 \\
- 2012).
\end{tabular}

erupsi 2010. Estimasi kerugian sektor peternakan khusus di Kabupaten Sleman yang disebabkan oleh kematian ternak, penurunan harga output, penurunan produksi susu dan lumpuhnya jaringan pemasaran menurut Ilham dan Priyanti (2011) mencapai $21 \mathrm{M}$. Seiring berjalannya waktu dan dengan adanya program penggantian sapi perah oleh pemerintah, baik untuk sapi perah yang mati dan yang ditinggal di lokasi bencana oleh peternak saat mengungsi, memungkinkan peternak sapi perah untuk kembali beternak.

Penghidupan berkelanjutan menurut Scoones (1995) meliputi kemampuan, aset (termasuk material dan sumber daya sosial) dan kegiatan yang diperlukan untuk sarana hidup. Dikatakan berkelanjutan apabila mata pencaharian itu mampu mengatasi dan pulih dari stres dan guncangan, memelihara atau meningkatkan kemampuan dan aset, sedangkan disatu sisi tidak merusak sumber daya alam.

Penerapan pendekatan penghidupan berkelanjutan dalam masyarakat rentan bahaya Gunungapi Pinatubo menurut Kelman dan Mather (2008) dapat dilihat dari 4 cara berikut: (1) pemahaman komunikasi dan pengelolaan kerentanan dan persepsi risiko masyarakat lokal mengenai kerentanan dan risiko yang mengancam kehidupan mereka, (2) memaksimalkan keuntungan masyarakat dari lingkungan volkan tanpa meningkatkan kerentanannya selama periode tidak aktif, (3) mengelola krisis ketika terjadi bencana alam dan 4) mengelola rekonstruksi dan permukiman kembali setelah periode krisis. Berdasarkan studi tersebut dapat dilihat bahwa penghidupan orang di sekitar wilayah volkan telah dengan baik diadaptasikan. Berdasar latar belakang tersebut, peneliti tertarik untuk mengetahui bagaimana strategi peternak sapi perah di lereng selatan gunungapi Merapi dalam rangka mempertahankan sumber penghidupan pasca erupsi 2010.

\section{Materi dan Metode}

\section{Materi}

Materi penelitian ini meliputi 84 peternak sapi perah di KRB III (Dusun Kaliadem) dan 50 peternak sapi perah di KRB II (Dusun Gondang Wetan). Lokasi penelitian adalah daerah rawan bencana, yang secara langsung terkena dampak dari erupsi Merapi 2010. Desa di daerah bencana dipilih dengan pertimbangan memiliki populasi sapi perah terbanyak pada saat sebelum letusan Merapi 2010 dan merupakan desa terdekat dengan puncak Merapi. Sampel atau materi penelitian adalah peternak sapi perah di daerah rawan bencana terpilih. Responden memiliki beberapa kriteria: 1) merupakan warga yang menetap di lokasi tersebut sejak sebelum 26 Oktober 2010, dengan dasar pemikiran bahwa responden pernah mengalami sedikitnya satu kali dalam perjalanan hidupnya menghadapi bahaya erupsi dari Gunungapi Merapi, 2) memelihara ternak sapi perah minimal satu tahun, dan 3) tinggal di Kecamatan Cangkringan. Peta Kecamatan Cangkringan secara detil dapat diamati pada Gambar 1.

\section{Metode}

Penelitian dilakukan dengan metode survei rumah tangga dengan wawancara langsung melibatkan responden yang dipilih. Metode pengambilan sampel dilakukan dengan menggunakan sensus, yaitu dengan mengambil semua peternak yang memenuhi kualifikasi. Guna mengetahui strategi peternak, digunakan metode deskriptif ialah menggali sebanyak mungkin informasi yang berkaitan dengan penghidupan mereka, meliputi tiga aspek penting yaitu aset (livelihood resources), akses dan aktivitas. Analisis penghidupan berkelanjutan menggunakan pendekatan sesuai konsep kerangka analisis menurut Scoones, 1995. Aset mencakup segala sesuatu mengenai 
potensi sumber daya yang dimiliki oleh peternak serta tingkat penggunaan dan peluang yang tersedia untuk pengembangan penghidupan yang berkelanjutan. Sumber daya dimaksud meliputi sumber daya alam (natural capital), sumber daya finansial/ekonomi (economic/financial capital), sumber daya fisik, sumber daya manusia (human capital) dan sumber daya sosial (social capital). Akses mempelajari proses kelembagaan dan struktur organisasi, ialah analisis tentang proses institusional dan

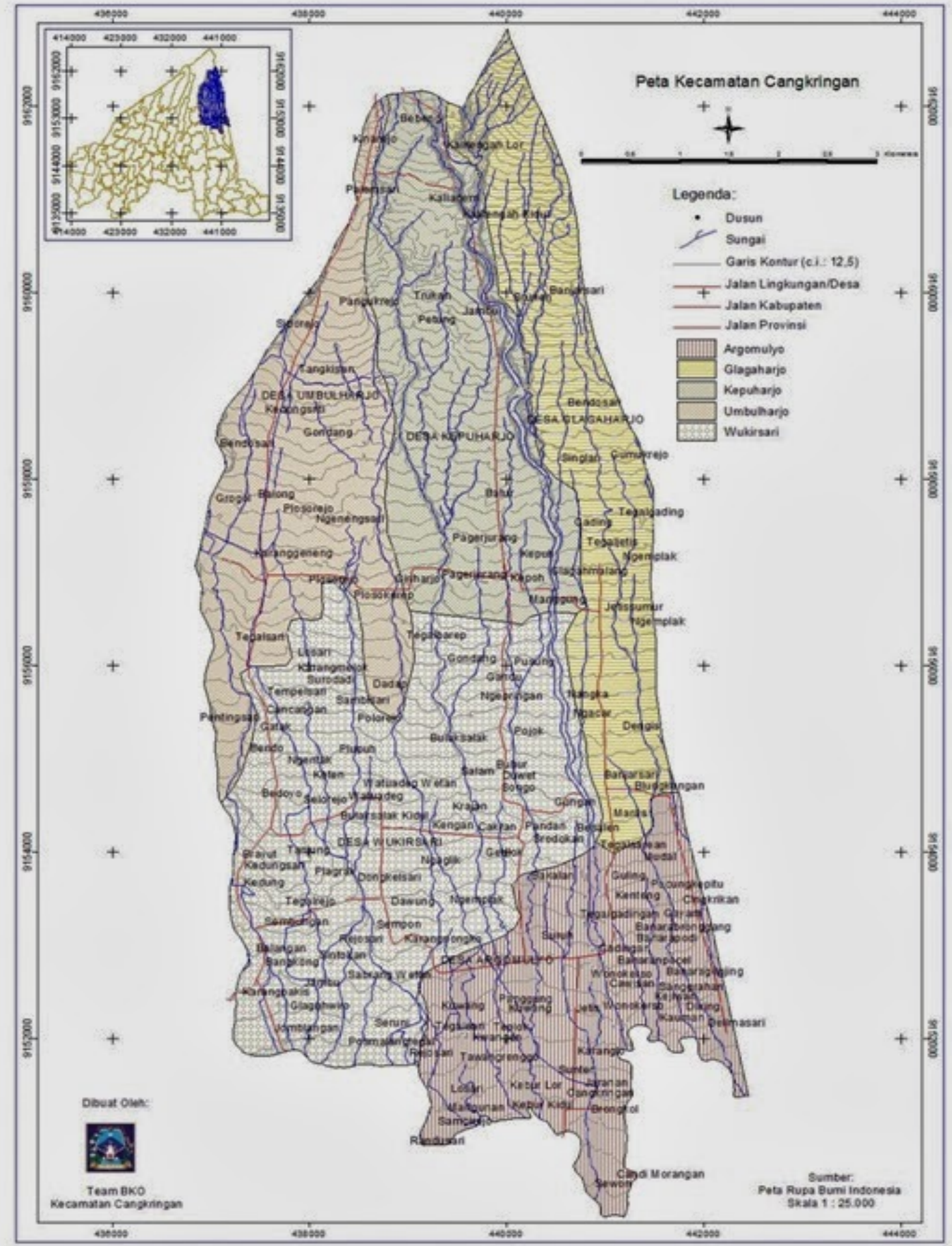

Gambar 1. Peta Kecamatan Cangkringan (Sumber: Kecamatan Cangkringan). 
struktur organisasi yang menentukan pilihan penghidupan bagi peternak sapi perah. Aktivitas adalah serangkaian kegiatan peternak yang dilakukan untuk mempertahankan sumber penghidupan.

Analisis strategi dan pilihan jalur-jalur penghidupan yang dipilih kemudian dikelompokkan dalam berbagai strategi. Analisis statistik yang digunakan untuk klasifikasi strategi penghidupan ialah Analisis Faktor dengan bantuan program SPSS versi 18. Analisis Faktor merupakan suatu alat uji untuk banyak variabel di mana untuk mengamati dan menganalisis suatu fenomena yang dapat dibuat suatu pola. Variabel-variabel yang banyak dan tidak terobservasi disebut sebagai faktor. Pada dasarnya model ini adalah pendorong bagi pembentukan suatu argumentasi. Variabelvariabel yang terdapat dalam model ini akan dikelompokkan berdasarkan hubungan antar variabel tersebut (Ghozali, 2001).

\section{Hasil dan Pembahasan}

\section{Hasil analisis}

Peternak sapi perah di lokasi penelitian (Dusun Kaliadem dan Gondang Wetan) memiliki karakteristik yaitu rerata kepemilikan sapi setelah erupsi Merapi tahun 2010 sebesar 2,46 ekor per peternak, yang mengindikasikan bahwa peternak termasuk dalam kategori peternak rakyat, meskipun peternakan merupakan mayoritas pekerjaan pokok. Lama domisili 46,87 tahun. Lama domisili yang relatif cukup lama, memberikan gambaran bahwa peternak sebenarnya sudah sangat familiar dengan kondisi geografis dan kemasyarakatan (sosial budaya) di lereng Merapi, termasuk dalam menghadapi aktivitas vulkanik. Umur rerata responden 48,37 tahun. Umur ini masih termasuk dalam usia produktif untuk bekerja, sehingga memungkinkan untuk mengembangkan diri baik dari segi pengetahuan maupun ketrampilan dalam beternak. Pendidikan formal yaitu jumlah tahun yang dihabiskan untuk menempuh pendidikan formal 6,75 tahun. Rerata pendidikan peternak tidak tamat SMP dalam menempuh pendidikan formal. Pendidikan peternak masih tergolong rendah, yang berarti secara rerata peternak belum menyelesaikan pendidikan dasar 9 tahun. Tingkat pendidikan sejalan dengan tingkat produktivitas dan efisiensi kerja. Semakin tinggi kompleksitas pekerjaan, membutuhkan pendidikan yang lebih tinggi pula (Djamali, 2000). Pemilikan lahan sebagai salah satu aset bagi peternak sebesar 3.412,98 $\mathrm{m}^{2}$ menunjukkan bahwa kepemilikan lahan sebagai aset hak milik cukup luas perpeternak, yang dimungkinkan sebagai modal untuk usaha sapi perah, terutama untuk lahan hijauan pakan ternak.

Analisis Faktor dilakukan dengan memasukkan 34 variabel, yang terdiri dari 20 variabel aset, 10 variabel akses dan 4 variabel aktivitas. Pemilihan variabel melalui tiga kali tahapan pengujian dengan 44 variabel awal. Hasil analisis faktor dengan 34 variabel menunjukkan nilai $\mathrm{KMO}$ dan Bartlett's Test 0,795 ( $P>0,05)$ yang berarti bahwa analisis termasuk kategori "lebih dari cukup", sehingga layak untuk kepentingan analisis faktor. Oleh karena itu, variabelvariabel tersebut dapat dianalisis lebih lanjut. Nilai sig. 0,000 $(P<0,05)$ berarti matriks korelasi bukan merupakan matriks identitas, sehingga dapat dilakukan analisis komponen utama.

Hasil analisis lanjutan menunjukkan bahwa nilai Anti-image Matrices (MSA) untuk semua variabel analisis, memiliki nilai lebih dari 0,05 sehingga semua variabel tersebut secara parsial layak untuk dianalisis berikutnya. Hasil analisis juga menunjukkan bahwa dari 34 variabel, 33 variabel memiliki nilai ekstraksi lebih dari 0,5 artinya variabel tersebut memiliki hubungan yang kuat dengan faktor yang terbentuk. Terdapat satu variabel yang memiliki nilai ekstraksi kurang dari 0,5 sehingga variabel tersebut dikatakan memiliki hubungan yang lemah dengan faktor yang terbentuk. Variabel aset kepemilikan simpanan di bank merupakan satu-satunya variabel yang memiliki nilai ekstraksi $<0,5$ sehingga variabel ini memiliki hubungan yang lemah dengan faktor yang terbentuk. Semakin besar nilai communalities, yang tercermin dari nilai MSA maka semakin baik analisis faktor, karena semakin besar karakteristik variabel asal yang dapat diwakili oleh faktor yang terbentuk.

Hasil analisis nilai Eigenvalues (Tabel 2), teramati dari 34 variabel yang dianalis menunjukkan bahwa terdapat 9 komponen yang memiliki nilai lebih besar dari satu, sehingga 9 komponen itulah yang dipakai dalam pembentukan faktor baru. Nilai kumulatif sebesar $72,89 \%$ berarti bahwa 
persentase kumulatif varian sebesar $72,89 \%$ yang dapat dijelaskan oleh faktor. Nilai Eigenvalues juga dapat ditampilkan dalam bentuk Scree Plot (Gambar 2), yang membantu peneliti menentukan berapa banyak faktor terbentuk yang dapat mewakili keragaman peubah-peubah asal. Apabila kurva masih terlihat curam, akan ada petunjuk untuk menambahkan komponen.

Hasil akhir analisis faktor dapat dilihat pada Tabel 3 Ratated component matrix, yang merupakan hasil dari rotasi faktor dengan metode Varimax. Rotasi Varimax adalah rotasi orthogonal yang membuat jumlah varian faktor loading dalam masingmasing faktor akan menjadi maksimum, dimana nantinya, peubah asal hanya akan mempunyai korelasi tinggi (bertanda*) dan kuat dengan faktor tertentu saja (korelasinya mendekati nilai satu), dan tentunya memiliki korelasi yang lemah dengan faktor yang lain (korelasi mendekati nilai nol). Tanda negatif (-) hanya menunjukkan arah korelasi.

Nilai Rotated component matrix menjadi dasar pemilihan variabel apa saja yang masuk dalam komponen yang terbentuk, dengan melihat faktor loading yang terbesar terdapat di komponen mana. Berdasar hasil analisis dari Tabel 3, dapat dijabarkan secara rinci dalam sembilan komponen strategi penghidupan yang dipilih oleh peternak sapi perah di lereng selatan Merapi pasca erupsi 2010 (Tabel 4). Pemberian nama strategi didasarkan pada variabel pembentuk komponen sebagaimana dapat diamati dalam Tabel 4, yaitu sebagai berikut: a) Strategi l: "Kombinasi pemanfaatan aset finansial, fisik dan sumber daya alam dengan mempertahankan usaha sapi perah", terdiri dari 6 variabel pembentuk komponen; b) Strategi II: "Kombinasi pemanfaatan aset fisik dan sosial, akses sosial serta diversifikasi usaha”, terdiri dari 8 variabel pembentuk komponen; c) Strategi III: "Pemanfaatan akses sosial", terdiri dari 3 variabel pembentuk komponen; d) Strategi IV: "Pemanfaatan bantuan dan akses sosial secara timbal balik", dengan 5 variabel pembentuk komponen; e) Strategi V: "Pemanfaatan liquid aset dan modal sosial",

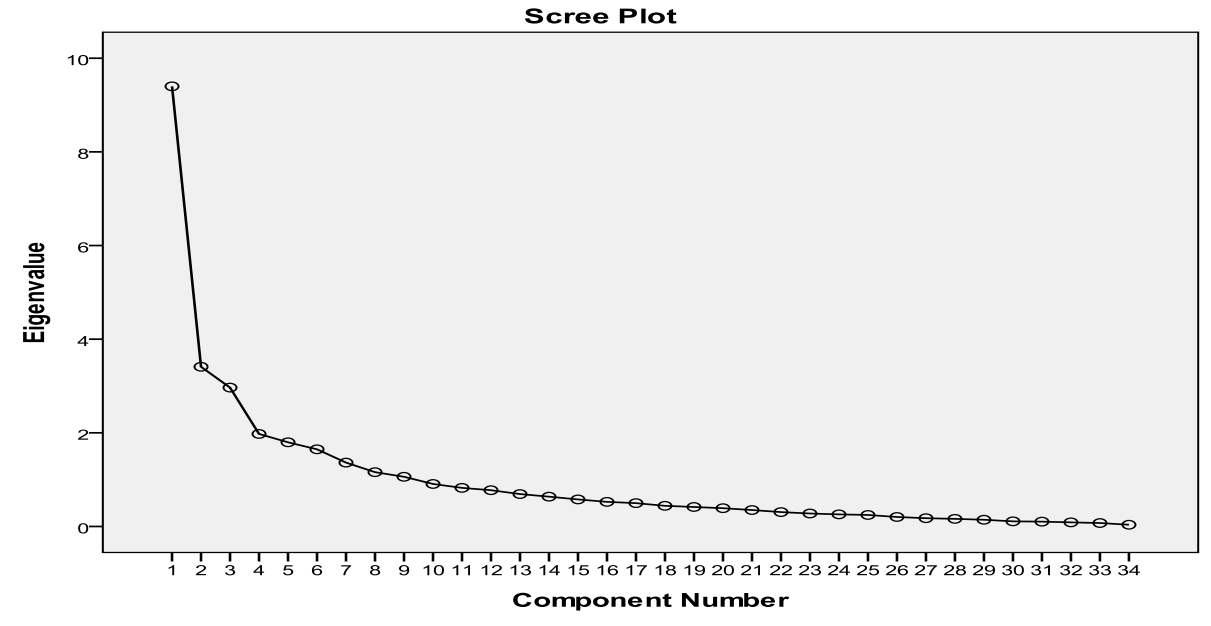

Gambar 2. Scree Plot (Sumber: Analisis data primer, 2016).

Tabel 2. Sumbangan komponen utama (total variance explained)

\begin{tabular}{cccc}
\hline \hline \multirow{2}{*}{$\begin{array}{c}\text { Komponen utama } \\
\text { (main component) }\end{array}$} & \multicolumn{3}{c}{ Nilai awal Eigenvalues (initial Eigenvalues) } \\
\cline { 2 - 4 } & Total (total) & $\begin{array}{c}\text { Persentase varians } \\
\text { percentage variance) }\end{array}$ & $\begin{array}{c}\text { Komulatif }(\%) \\
\text { (cumulative (\%)) }\end{array}$ \\
\hline 1 & 9,399 & 27,645 & 27,645 \\
2 & 3,410 & 10,030 & 37,675 \\
3 & 2,966 & 8,723 & 46,398 \\
4 & 1,976 & 5,812 & 52,209 \\
5 & 1,798 & 5,287 & 57,496 \\
6 & 1,648 & 4,846 & 62,343 \\
7 & 1,364 & 4,012 & 66,355 \\
8 & 1,160 & 3,411 & 69,766 \\
9 & 1,061 & 3,121 & 72,887 \\
\hline
\end{tabular}

Sumber: Analisis data primer (2016). 
Buletin Peternakan Vol. 41 (1): 91-100, Februari 2017

Bulletin of Animal Science, DOI: 10.21059/buletinpeternak.v41i1.12768

Tabel 3. Rotated component matrix

\begin{tabular}{|c|c|c|c|c|c|c|c|c|c|}
\hline \multirow{2}{*}{$\begin{array}{c}\text { Variabel } \\
\text { (variable) }\end{array}$} & \multicolumn{9}{|c|}{ Komponen (component) } \\
\hline & 1 & 2 & 3 & 4 & 5 & 6 & 7 & 8 & 9 \\
\hline VAR00003 & $-.552^{*}$ & -.096 & -.202 & .035 & .083 & .008 & .141 & -.092 & -.102 \\
\hline VAR00005 & .375 & .287 & .090 & .017 & -.111 & .167 & $.637^{*}$ & .135 & .181 \\
\hline VAR00006 & .284 & .095 & .261 & .040 & -.199 & .044 & $.546^{*}$ & .454 & -.016 \\
\hline VAR00008 & -.112 & -.145 & .359 & .236 & $-.405^{\star}$ & 131 & .259 & -.156 & . 184 \\
\hline VAR00009 & $.541 *$ & .410 & 399 & .266 & -.151 & .266 & -.214 & .082 & -.029 \\
\hline VAR00010 & .437 & $.444^{*}$ & .436 & .398 & -.124 & .056 & .179 & -.040 & .100 \\
\hline VAR00011 & $.512^{*}$ & .424 & .264 & .311 & -.130 & .239 & -.033 & -.057 & .024 \\
\hline VAR00012 & $.887^{*}$ & .034 & .078 & .122 & -.059 & .153 & .062 & -.079 & .033 \\
\hline VAR00014 & $.885^{*}$ & .105 & .102 & .014 & .034 & 149 & .183 & -.018 & -.052 \\
\hline VAR00015 & .036 & -.066 & .183 & .149 & .176 & .215 & .053 & -.104 & $.726^{*}$ \\
\hline VAR00016 & -.453 & $-.476^{*}$ & -.391 & -.366 & .111 & -.073 & .092 & -.020 & -.198 \\
\hline VAR00017 & -.072 & .014 & .021 & .066 & -.131 & .130 & .029 & $.723^{*}$ & -.046 \\
\hline VAR00019 & -.279 & .130 & .265 & .237 & -.206 & $-.423^{*}$ & .159 & .264 & .347 \\
\hline VAR00020 & -.205 & .046 & $-.831^{*}$ & .116 & .050 & -.075 & -.085 & -.015 & .070 \\
\hline VAR00021 & -.109 & -.039 & -.004 & -.201 & $.892^{*}$ & -.114 & .050 & -.081 & .111 \\
\hline VAR00022 & -.137 & -.100 & .014 & -.113 & $.904^{*}$ & -.123 & -.002 & -.146 & .065 \\
\hline VAR00026 & .464 & $.466^{*}$ & .085 & .038 & .027 & .217 & -.289 & .371 & -.028 \\
\hline VAR00027 & -.191 & .043 & $-.704^{*}$ & .155 & .008 & -.233 & .039 & -.267 & -.275 \\
\hline VAR00028 & -.133 & -.009 & $-.862^{*}$ & .072 & -.048 & -.103 & -.116 & .045 & -.094 \\
\hline VAR00029 & .183 & .284 & .438 & .046 & 177 & $.509^{*}$ & .072 & .064 & -.297 \\
\hline VAR00030 & .451 & $.498^{*}$ & 156 & .312 & .065 & .432 & -.037 & .126 & .073 \\
\hline VAR00031 & -.319 & $-.606^{*}$ & .196 & .020 & -.055 & .065 & .052 & -.259 & -.433 \\
\hline VAR00032 & .215 & -.021 & .254 & .084 & -.233 & $.702 *$ & .212 & .207 & .182 \\
\hline VAR00033 & -.223 & .000 & -.190 & -.068 & .267 & $-.775^{*}$ & -.090 & -.126 & -.148 \\
\hline VAR00034 & .145 & $.483^{*}$ & .101 & .182 & -.167 & .464 & -.158 & .082 & .285 \\
\hline VAR00035 & .028 & .054 & -.241 & $.717^{*}$ & .045 & -.213 & .019 & .183 & .222 \\
\hline VAR00036 & .090 & .040 & -.037 & $.732^{*}$ & -.367 & .019 & .008 & -.199 & .028 \\
\hline VAR00037 & .113 & 176 & .048 & $.582^{*}$ & 182 & 199 & -.136 & .418 & .065 \\
\hline VAR00038 & -.003 & .044 & -.047 & $.636^{*}$ & -.108 & 247 & -.250 & 183 & -.219 \\
\hline VAR00039 & .124 & -.109 & -.025 & $.786^{*}$ & -.228 & .068 & .154 & -.063 & .095 \\
\hline VAR00040 & $.898^{*}$ & .093 & .074 & .066 & -.107 & .133 & .052 & .008 & -.033 \\
\hline VAR00042 & -.296 & -.260 & .085 & -.101 & .204 & .047 & $.645^{*}$ & -.164 & -.074 \\
\hline VAR00043 & .208 & $.706^{*}$ & -.005 & .047 & -.237 & -.049 & 190 & .065 & -.152 \\
\hline VAR00044 & -.055 & $.820^{*}$ & -.089 & -.118 & .107 & -.002 & -.046 & -.077 & -.085 \\
\hline
\end{tabular}

terdiri dari 3 variabel pembentuk; f) Strategi VI: "Kombinasi faktor psikologis dengan pemanfaatan akses sosial dan finansial", terbentuk dari 4 variabel pembentuk komponen; g) Strategi VII: "Pemanfaatan aset dan akses finansial serta penggunaan waktu jeda", dengan 3 variabel pembentuk komponen; h) Strategi VIII: "Pemanfaatan modal sosial", yang hanya terdiri dari satu variabel pembentuk komponen; i) Strategi IX: "Diversifikasi usaha peternakan", ialah strategi yang didasarkan pada kepemilikan ternak lain saat ini.

\section{Pembahasan umum}

Sembilan strategi penghidupan yang dipilih dan dilakukan oleh peternak sapi perah di lereng selatan gunungapi Merapi, merupakan pilihan dari satu variabel (aset, akses, aktivitas) maupun kombinasi dari beberapa variabel, tergantung dari karakteristik dan kemampuan dari masing- masing peternak. Kombinasi pemanfaatan aset finansial, fisik dan sumber daya alam dengan mempertahankan usaha sapi perah, merupakan salah satu strategi paling dominan yang dipilih oleh peternak, dengan nilai kumulatif yang paling besar $(27,645 \%)$. Peternakan merupakan sumber penghidupan berkelanjutan, yang mampu bertahan terhadap goncangan (erupsi Merapi), meskipun memerlukan waktu jeda. Peternakan juga secara relatif tidak merusak sumber daya alam, karena hanya memanfaatkan apa yang tersedia di lingkungan sekitar, tanpa menimbulkan kerusakan untuk hutan rakyat di lereng Merapi; baik sebagai sumber diversifikasi flora fauna maupun daerah tangkapan air, hal ini sesuai dengan pendapat Scoones (1995).

Peternakan dengan nilai ekonominya yang terbukti positip (Widiati et al., 2007), menjadi salah satu alternatif sumber 
Tabel 4. Komponen strategi penghidupan peternak sapi perah (component of dairy farmers livelihood strategies)

\begin{tabular}{|c|c|c|}
\hline $\begin{array}{c}\text { Strategi } \\
\text { penghidupan } \\
\text { (livelihood } \\
\text { strategies) } \\
\end{array}$ & $\begin{array}{c}\text { Nomor } \\
\text { variabel } \\
\text { (number of } \\
\text { variable) }\end{array}$ & Komponen (component) \\
\hline \multirow[t]{6}{*}{ I } & 3 & Kepemilikan simpanan di bank (deposits ownership in banks) \\
\hline & 9 & Kepemilikan rumah tinggal (residential ownership) \\
\hline & 11 & Kepemilikan lahan pertanian (agricultural land ownership) \\
\hline & 12 & Kepemilikan lahan khusus hijauan pakan ternak (forage land ownership) \\
\hline & 14 & Kepemilikan ternak sapi perah (dairy cattle ownership) \\
\hline & 40 & Status usaha sapi perah saat ini (current status of the dairy cattle business) \\
\hline \multirow[t]{8}{*}{ II } & 10 & $\begin{array}{l}\text { Kepemilikan bangunan fisik untuk tempat usaha, seperti kandang, toko dll) } \\
\text { (physical building ownership for the business, such as stables, shops etc) }\end{array}$ \\
\hline & 16 & Lama domisili (length of stay) \\
\hline & 26 & $\begin{array}{l}\text { Keikutsertaan pertemuan rutin warga pada tingkat RW (the participation in regular } \\
\text { meetings at the local community) }\end{array}$ \\
\hline & 30 & $\begin{array}{l}\text { Bantuan tenaga kerja dari sanak saudara maupun tetangga untuk pemulihan } \\
\text { tempat tinggal (labor aid from family and neighbors for shelter recovery) }\end{array}$ \\
\hline & 31 & Jumlah bantuan tenaga kerja yang didapat (the amount of aid workers obtained) \\
\hline & 34 & Aktivitas membantu tenaga ke orang lain (physical activities to help others) \\
\hline & 43 & Cara memenuhi kebutuhan hidup (ways to fulfil the life's needs) \\
\hline & 44 & Pekerjaan yang dilakukan sekarang (current job) \\
\hline \multirow[t]{3}{*}{ III } & 20 & $\begin{array}{l}\text { Kemudahan memperoleh bantuan dari orang lain (ease in obtaining help from } \\
\text { others) }\end{array}$ \\
\hline & 27 & $\begin{array}{l}\text { Keikutsertaan pada pertemuan rutin warga pada tingkat dusun (the participation } \\
\text { in regular meetings at the village) }\end{array}$ \\
\hline & 28 & $\begin{array}{l}\text { Keikutsertaan pada pertemuan lain, selain RT, RW, Dusun (the participation in } \\
\text { the meetings other than local community) }\end{array}$ \\
\hline \multirow[t]{5}{*}{ IV } & 35 & $\begin{array}{l}\text { Bantuan uang dari sanak saudara maupun tetangga (funding aid from family and } \\
\text { neighbors) }\end{array}$ \\
\hline & 36 & $\begin{array}{l}\text { Aktivitas membantu uang untuk sanak saudara dan tetangga (activities to give } \\
\text { funding for family and neighbors) }\end{array}$ \\
\hline & 37 & $\begin{array}{l}\text { Bantuan barang dari sanak saudara maupun tetangga (goods sharing from family } \\
\text { and neighbors) }\end{array}$ \\
\hline & 38 & $\begin{array}{l}\text { Aktivitas membantu barang untuk sanak saudara dan tetangga (activities to share } \\
\text { goods for family and neighbors) }\end{array}$ \\
\hline & 39 & $\begin{array}{l}\text { Aktivitas memberi pinjaman uang pada sanak saudara maupun tetangga (activities } \\
\text { to lend money to family and neighbors) }\end{array}$ \\
\hline \multirow[t]{3}{*}{$\mathrm{V}$} & 8 & $\begin{array}{l}\text { Kepemilikan aset lain yang sewaktu-waktu bisa dijual dan digunakan sebagai } \\
\text { modal usaha (other assets ownership that can be sold at any time and used as } \\
\text { capital) }\end{array}$ \\
\hline & 21 & $\begin{array}{l}\text { Aktivitas jumlah kehadiran pada acara perkawinan selama } 2 \text { bulan terakhir } \\
\text { (attendance at the wedding party during the last } 2 \text { months) }\end{array}$ \\
\hline & 22 & $\begin{array}{l}\text { Jumlah undangan perkawinan yang diterima } 2 \text { bulan terakhir (number of wedding } \\
\text { party invitations received during the last } 2 \text { months) }\end{array}$ \\
\hline \multirow[t]{4}{*}{ VI } & 19 & Perasaan aman tinggal di daerah ini (safety feeling during the stay in this area) \\
\hline & 29 & $\begin{array}{l}\text { Jumlah pertemuan lain (selain RT, RW, Dusun) yang diikuti (number of other local } \\
\text { community meetings followed) }\end{array}$ \\
\hline & 32 & $\begin{array}{l}\text { Aktivitas meminjam uang untuk pemulihan tempat tinggal (activities to borrow } \\
\text { money for the house recovery) }\end{array}$ \\
\hline & 33 & Asal kredit untuk pemulihan rumah (source of credit for the house recovery) \\
\hline \multirow[t]{3}{*}{ VII } & 5 & Kepemilikan piutang pada pihak lain (earnings ownership from other parties) \\
\hline & 6 & $\begin{array}{l}\text { Aktivitas meminjam uang dari bank atau lembaga keuangan lain untuk modal } \\
\text { (activities to borrow money from banks or other financial institutions for capital) }\end{array}$ \\
\hline & 42 & Aktivitas produktif selama waktu jeda (productive activities during the time interval) \\
\hline VIII & 17 & $\begin{array}{l}\text { Kepemilikan kerabat dari pihak suami yang tinggal dalam satu desa (the } \\
\text { availability of husband's family who lived in the same village) }\end{array}$ \\
\hline IX & 15 & Kepemilikan ternak lain (other livestock ownership) \\
\hline
\end{tabular}

penghidupan terbesar bagi peternak di lereng selatan gunungapi Merapi. Peternakan sapi perah telah secara turuntemurun diadaptasi masyarakat selama puluhan tahun. Sejalan dengan pendapat Kelman dan Mather (2008), maka seharusnya peternakan sapi perah menjadi fokus perhatian pemerintah dalam proses 
pengelolaan krisis ketika terjadi bencana alam serta pengelolaan rekonstruksi dan permukiman kembali setelah periode krisis. Hal ini untuk memaksimalkan keuntungan masyarakat dari lingkungan volkan tanpa meningkatkan kerentanannya selama periode tidak aktif.

Terdapat satu variabel baru yang merupakan temuan baru sekaligus koreksi dalam teori yang mempelajari strategi penghidupan berkelanjutan menurut Scoones (1995), yaitu dengan masuknya variabel psikologis (rasa aman). Sumber daya manusia menurut Scoones hanya mencakup keahlian/keterampilan, pengetahuan, kemampuan tenaga kerja dan kesehatan serta kemapuan fisik yang baik, tanpa memasukkan aspek psikologis. Variabel psikologis, merupakan variabel yang sifatnya bebas (independent). Variabel psikologis dapat mempengaruhi aktivitas sosial maupun ekonomi yang dilakukan oleh seorang peternak.

Fenomena lain yang menarik dalam penelitian ini adalah: variabel modal sosial merupakan faktor yang mendominasi dasar pilihan strategi peternak sapi perah, ialah dengan mendasari 6 dari 9 pilihan strategi penghidupan yang dipilih untuk menjamin penghidupan yang berkelanjutan pasca erupsi Merapi 2010. Hasil penelitian serupa terjadi pasca gempa bumi di Yogyakarta tahun 2006, di mana masyarakat setempat telah berhasil dalam memulihkan mata pencaharian mereka menggunakan sumber daya lokal dan modal sosial (Rijanta, 2010).

Hal lain yang juga perlu dicatat, tidak ada peternak yang memilih untuk melakukan strategi migrasi secara personal dan permanen. Kondisi ini dimungkinkan karena eratnya nilai-nilai sosial dan budaya dengan segala kekerabatannya bagi masyarakat di lereng selatan Merapi, sesuai dengan pendapat Laksono (1998) cit. Lavigne et al. (2008). Pemahaman mengenai pendekatan strategi penghidupan yang berkelanjutan yang dipilih oleh peternak, seharusnya dapat dijadikan dasar pertimbangan bagi pemerintah dan instansti terkait pembuat kebijakan sebagai dasar dalam skenario strategi untuk pengurangan risiko bencana, hal ini sejalan dengan pendapat Tobin dan Whiteford (2002). Tantangan utama pemerintah dalam pemulihan ekonomi pasca bencana adalah bagaimana membangun kembali matapencaharian dengan basis ekonomi masyarakat yang sudah berkembang di daerah tersebut (FAO, 2005).

\section{Kesimpulan}

Terdapat sembilan komponen strategi yang dipilih oleh peternak sapi perah dalam mempertahankan sumber penghidupan guna menjamin penghidupan yang berkelanjutan, yaitu: 1) Kombinasi pemanfaatan aset finansial, fisik dan sumber daya alam dengan mempertahankan usaha sapi perah, 2) Kombinasi pemanfaatan aset fisik dan sosial, akses sosial serta diversifikasi usaha, 3) Pemanfaatan akses sosial, 4) Pemanfaatan bantuan dan akses sosial secara timbal balik, 5) Pemanfaatan liquid aset dan modal sosial, 6) Kombinasi faktor psikologis dengan pemanfaatan akses sosial dan finansial, 7) Pemanfaatan aset dan akses finansial serta penggunaan waktu jeda, 8) Pemanfaatan modal sosial, dan 9) Diversifikasi usaha peternakan. Peternakan sapi perah masih menjadi pilihan strategi yang paling dominan bagi peternak sapi perah di lereng selatan Gunungapi Merapi pasca erupsi Merapi 2010 yang menjamin keberlanjutan bagi kehidupan mereka. Variabel psikologis (rasa aman), merupakan temuan baru dalam teori yang mempelajari strategi penghidupan berkelanjutan. Variabel ini dapat mempengaruhi aktivitas sosial maupun ekonomi yang dilakukan oleh seorang peternak. Modal sosial adalah variabel yang mendominasi dasar pilihan strategi peternak sapi perah, ialah dengan mendasari 6 dari 9 pilihan strategi yang dipilih untuk menjamin penghidupan yang berkelanjutan pasca erupsi Merapi 2010. Oleh karena itu, peternak didampingi instansi terkait sebaiknya mempertahankan dan meningkatkan peran modal sosial dan aset kelembagaan berupa kelompok ternak dan koperasi yang sudah ada. Hal ini dalam rangka pengembangan kegiatan peternakan di lereng selatan gunungapi Merapi untuk menjamin kelangsungan sumber mata pencaharian maupun sosialisasi kebijakan pemerintah terkait mitigasi bencana gunungapi Merapi.

\section{Daftar Pustaka}

Badan Pusat Statistik Kabupaten Sleman. 2012. Kecamatan Cangkringan Dalam 
Angka 2012. Badan Pusat Statistik Kabupaten Sleman, Yogyakarta.

BNPB. 2010. Kawasan Rawan Bencana Erupsi Merapi 2010. Badan Nasional Penanggulangan Bencana. 18 November 2010, Yogyakarta.

Djamali, A. R. 2000. Manajemen Usahatani. Departemen Pendidikan Nasional Politeknik Pertanian Negeri Jember. Jurusan Manajemen Agribisnis, Jember.

FAO. 2005. Tsunami Communities Reborn; Rebuilding livelihoods better than before. http://www.fao.org./ reliefoperations. Accessed 10 August 2016.

Ghozali, I. 2001. Aplikasi Analisis Multivariat Dengan Program SPSS. Undip Press, Semarang.

Ilham, N. dan Priyanti, A. 2011. Dampak Bencana Merapi Terhadap Usaha Sapi Perah di Kabupaten Sleman. WARTAZOA. Buletin IImu Peternakan dan Kesehatan Hewan Indonesia 21: 161-170.

Kelman, I. and T. A. Mather. 2008. Living with volcanoes: The sustainable livelihoods approach for volcanorelated opportunities. Journal of Volcanology and Geothermal Research 172: 189-198.

Lavigne, F., B. De Coster, N. Juvin, F. Flohic, C. J. Gaillard, P. Texier, J. Morin and
J. Saptohadi. 2008. People's Behaviour in the face of volcanic hazards: Perspectives from Javanesse communities, Indonesia, Journal of Volcanology and Geothermal Research 172: 273-287.

Rijanta, R. 2010. Livelihood Rehabilitation Strategy Based on Local Resources: Lessons Learned from Yogyakarta Special Province After a four Year Rehabilitation. Working paper, RCUSS Kobe University, Japan.

Scoones, I. 1995. Sustainable Rural Livelihoods A Framework For Analysis. IDS Working Papers 72. http://www.ids.ac.uk.download.cfm?file =wp72.pdf. 10 August 2016.

Tobin, G. A. and L. M. Whiteford. 2002 Community Resilience and Volcano Hazard: The Eruption of Tungurahua and Evacuation of The Faldas in Ecuador. Disaster 26: 28-48.

Widiati, R., Y. Y. Suranindyah, S. Andarwati, G. Suparta, dan A. Agus. 2007. Pengembangan Lembaga Keuangan Mikro Berbasis Pedesaan; Studi Kasus Pada Kelompok Penerima Bantuan Modal. Proseding Seminar Nasional Pemanfaatan Ipteks Dalam Rangka Penguatan dan Pemberdayaan Masyarakat, 21 April 2007, 37-42. 